UDC 332.02

LBC 65.050.23

\title{
NEW FORMS OF DIRECT PUBLIC PARTICIPATION IN LOCAL SELF-GOVERNMENT ${ }^{1}$
}

\author{
Valeriya A. Rodkina \\ Regional Center for Development and Quality Control of Social Services, Volgograd, Russian Federation \\ Nataliya A. Mikhaylova \\ Volgograd State University, Volgograd, Russian Federation
}

\begin{abstract}
In the modern realities, the hope of reinforcing the democratic civil society in Russia is associated with local self-government. However, the actual political situation gives grounds to assert that restructuring the Russian system, which has lasted over the past decades, did not make significant changes to the system of municipalities' interrelation. Today, such an important and urgent problem as the lack of active participation of citizens in resolving issues of local importance is more topical than ever. The problems of the population activity also acquire special significance in connection with the need of working out the strategies for sustainable development of municipalities, taking into account regional specifics.

The article deals with the various forms of Russian citizens' participation in local self-government. Based on the expert survey, the level of civic engagement of the population is analyzed, the main reasons for passivity of residents, the prospects for voters' participation in solving problems of local communities are determined. The authors reveal the unpreparedness of the population to take an active and permanent part in the implementation of local self-government, that is conditioned by a whole range of reasons, which are primarily subjective, and therefore it is expedient to involve citizens in solving local problems through the development of voluntary associations, whose activities would be directed at socially significant tasks.

Key words: system of state and municipal management, local self-government, active citizenship, local authorities, public initiative.
\end{abstract}

УДК 332.02

ББК 65.050 .23

\section{НОВЫЕ ФОРМЫ НЕПОСРЕДСТВЕННОГО УЧАСТИЯ НАСЕЛЕНИЯ В ОСУЩЕСТВЛЕНИИ МЕСТНОГО САМОУПРАВЛЕНИЯ ${ }^{1}$}

\author{
Валерия Александровна Родькина \\ Областной центр развития и контроля качества социальных услуг, \\ г. Волгоград, Российская Федерация
}

\section{Наталия Александровна Михайлова}

Волгоградский государственный университет, г. Волгоград, Российская Федерация

\footnotetext{
Аннотация. В современных условиях именно с местным самоуправлением связаны надежды на то, что демократическое гражданское общество в России будет только укреплять свои позиции. Однако реальная политическая ситуация дает основания утверждать, что перестройка российской системы, которая продолжалась последние десятилетия, не внесла значительных изменений в сложившуюся на уровне муниципалитетов систему взаимоотношений. Сегодня как никогда актуальна такая важная и требующая первоочередного решения проблема, как недостаточная активность участия граждан в разрешении вопросов местного значения. Проблемы активности населения приобретают особую значимость также в связи с необходимостью выработки стратегий устойчивого развития муниципальных образований с учетом реги() ональной специфики.
} 
В статье рассматриваются различные формы участия граждан России в местном самоуправлении. На основе экспертного опроса анализируется уровень гражданской активности населения, определяются основные причины пассивности жителей, перспективы участия избирателей в решении проблем местных сообществ. В исследовании выявлена неготовность населения принимать деятельное и постоянное участие в осуществлении местного самоуправления, что обусловлено целым комплексом причин, носящих, прежде всего, субъективный характер, следовательно, целесообразно вовлечение жителей в решение местных проблем через развитие добровольных объединений граждан, деятельность которых будет направлена на социально значимые задачи.

Ключевые слова: система государственного и муниципального управления, местное самоуправление, активная гражданская позиция, местная власть, инициативность населения.

Трансформации, наблюдаемые в России, не лишены проблем, в том числе и связанных с социально-экономическим развитием, которые наибольшим образом проявляются на территориях муниципальных образований. Зачастую органы местного самоуправления не имеют возможности разрешать проблемы самостоятельно, то есть без социального сотрудничества местной власти с гражданами. В таких условиях именно население, образуя общественные объединения и другие субъекты гражданского общества, способно взять на себя разрешение вопросов местного значения, а следовательно, и реализацию части функций местного самоуправления.

Федеральный закон о местном самоуправлении предоставил населению широкие права на самоуправление. К основным организационным формам осуществления местного самоуправления следует относить формы прямого волеизъявления граждан - референдум, муниципальные выборы, сход, собрания граждан, публичные слушания, конференции граждан, правотворческую инициативу, территориальное общественное самоуправление, которое представляет собой самоорганизацию граждан по месту их жительства на части территории муниципального образования [4, c. 130]. Все предусмотренные формы участия граждан в осуществлении местного самоуправления направлены на то, чтобы повышать интерес населения к участию в управлении, укреплять взаимосвязь граждан с органами местного самоуправления.

В реалиях современности ресурсы местного самоуправления используются не в полной мере, что обусловлено низкой социальной активностью граждан, которые устраняются от участия в решении вопросов местного значения. Низкая инициативность населения пре- вращает местное самоуправление в недостаточно эффективное управление.

Местная власть - это тот приводной ремень, который способен обеспечить выполнение любой стратегии федеральной и региональной власти, доведя ее до местного сообщества. Муниципальные руководители, которые знают особенности и проблемы территории и населяющих ее людей, имеют возможность предлагать более результативную тактику по реализации федеральных стратегий и проектов. Именно органы местного самоуправления имеют возможность обеспечивать для руководителей государства достоверную и непрерывную «обратную связь», предоставляя информацию о том, как выполняются важные национальные задачи на местах, об отношении граждан к разным инициативам власти, а при необходимости - и предложения по корректировке принятых решений [1, с. 11].

Таким образом, считаем, что разрешение многих проблемных аспектов, связанных с привлечением населения к участию в местном самоуправлении, напрямую находится в зависимости от органов местного самоуправления, которые призваны разрабатывать формы более результативного сотрудничества с населением муниципального образования. Первоочередная задача органов местного самоуправления - обеспечить условия, при которых у любого гражданина будет реальная возможность оказывать влияние на процессы выработки и принятия решений органами и должностными лицами местного самоуправления. Исторически неоднократно доказывалось, что местное самоуправление не будет долговечным, если отсутствует активная поддержка со стороны населения.

Разнообразные и сложные проблемы, которые имеют место на территории конк- 
ретного муниципального образования, специфика их восприятия жителями, бесспорно, оказывают влияние на уровень общественной активности. В то же время осознание проблемы большей частью населения - это недостаточное условие для того, чтобы возникла общественная активность. Активность населения по решению вопросов местного значения обусловлена совокупным комплексом различных факторов: экономических, политических, культурных, демографических и психологических.

На снижение социальной активности граждан зачастую оказывает влияние позиция местных властей, которые не заинтересованы проблемами граждан и часто стремятся подменять реальное сотрудничество его видимостью. Не редкостью являются случаи, когда общественная активность используется ради реализации политических или бизнеспроектов, преследующих цели, которые не совпадают с целями населения.

Люди, имеющие хорошее образование, информированные и материально обеспеченные, зачастую игнорируют интересы общества. Продолжается углубление конфликта между ценностями демократии и авторитаризма, развития и стабильности, индивидуальной свободы и коллективной ответственности [2, c. 183]. По мнению И.Н. Трофимовой, российские граждане имеют достаточно знаний и компетенций по главным вопросам жизнедеятельности своего муниципалитета, население понимает его жизнь изнутри. В то же время более половины граждан России не понимают, что значит «внести свои предложения на рассмотрение администрации» [6, с. 63].

Ряд исследователей отмечает то, что взаимодействие граждан и органов власти в нашей стране развито недостаточно. Если провести сравнение, то доля граждан, которые знают, как доносить свое мнение до властей, наиболее высока в развитых европейских странах: в Голландии - $67 \%$, Финляндии $58 \%$, Швеции - $54 \%$, Дании - $52 \%$; среди россиян $-16 \%$ [7, с. 102].

Исследователи указывают, что одной из причин низкой активности населения в решении местных проблем следует считать неверие большей части граждан в то, что они смогут оказать влияние на принятие решений и отсутствие баланса интересов муниципальной власти, государственной власти, населения, бизнеса. Для изучения данного вопроса нами был проведен анализ мнения экспертного сообщества, в состав которого вошли действующие руководители органов местного самоуправления, депутаты представительных органов власти, научные работники, исследующие местное самоуправление.

Опрос, направленный на изучение мнения представителей органов местного самоуправления об отношении населения к местному самоуправлению, проводился при помощи разработанного опросного листа, в котором содержалась информация о теме исследования, инструкция с указанием, каким образом нужно отмечать варианты ответов. В исследовании принимали участие 23 человека. Выборка была разделена преимущественно по возрастному цензу и по стажу трудовой деятельности, а именно: имеющих стаж работы руководителя от 5 до 10 лет - 17,39\% респондентов; от 10 до 20 лет - 47,83 \% респондентов и более 20 лет - 34,78 \%.

В ходе структурированного интервью основной исследовательской задачей стала оценка непосредственного участия населения в реализации своих гражданских прав на местное самоуправление и выявление мер, направленных на повышение общественной активности, в целях применения потенциала населения в помощь органам местного самоуправления в разрешении вопросов местного значения (см. табл. 1).

Таким образом, основными причинами, которые препятствуют проявлению инициатив граждан, являются причины законодательного характера, такие как отсутствие баланса интересов муниципальной власти, государственной власти, населения, бизнеса; несовершенное законодательство; бюрократия при взаимодействии с органами государственной власти; а также личные причины граждан занятость делами личного характера и неорганизованность жителей.

Не остался вне поля зрения и вопрос, почему, по мнению представителей власти, граждане не хотят принимать участие в местном самоуправлении (см. табл. 2).

Таким образом, мы можем увидеть, что основной причиной отказа от участия граж- 


\section{Причины, препятствующие проявлению инициатив граждан в местном самоуправлении}

\begin{tabular}{|c|c|c|c|c|c|c|c|c|}
\hline \multirow{3}{*}{$\begin{array}{c}\text { Причины, препятствующие проявлению } \\
\text { инициатив граждан }\end{array}$} & \multirow{2}{*}{\multicolumn{2}{|c|}{$\begin{array}{l}\text { Общее количест- } \\
\text { во респондентов }\end{array}$}} & \multicolumn{6}{|c|}{ Распределение в зависимости от стажа } \\
\hline & & & \multicolumn{2}{|c|}{ от 5 до 10 лет } & \multicolumn{2}{|c|}{ от 10 до 20 лет } & \multicolumn{2}{|c|}{ более 20 лет } \\
\hline & $\begin{array}{c}\text { Кол-во } \\
\text { чел. }\end{array}$ & $\%$ & $\begin{array}{c}\text { Кол-во } \\
\text { чел. }\end{array}$ & $\%$ & $\begin{array}{l}\text { Кол-во } \\
\text { чел. }\end{array}$ & $\%$ & $\begin{array}{c}\text { Кол-во } \\
\text { чел. }\end{array}$ & $\%$ \\
\hline $\begin{array}{l}\text { Отсутствие баланса интересов муници- } \\
\text { пальной власти, государственной власти, } \\
\text { населения, бизнеса }\end{array}$ & 16 & 69,57 & 3 & 13,04 & 7 & 30,43 & 6 & 26,09 \\
\hline Несовершенное законодательство & 15 & 65,22 & 4 & 17,39 & 5 & 21,74 & 6 & 26,09 \\
\hline Занятость делами личного характера & 13 & 56,52 & 4 & 17,39 & 7 & 30,43 & 2 & 8,70 \\
\hline $\begin{array}{l}\text { Бюрократия при взаимодействии с органа- } \\
\text { ми государственной власти }\end{array}$ & 12 & 52,17 & 2 & 8,70 & 5 & 21,74 & 5 & 21,74 \\
\hline Неорганизованность жителей & 12 & 52,17 & 3 & 13,04 & 5 & 21,74 & 4 & 17,39 \\
\hline $\begin{array}{l}\text { Отсутствие согласованности программных } \\
\text { документов }\end{array}$ & 9 & 39,13 & 2 & 8,70 & 4 & 17,39 & 3 & 13,04 \\
\hline $\begin{array}{l}\text { Недостаточная финансовая поддержка со } \\
\text { стороны государства }\end{array}$ & 5 & 21,74 & 1 & 4,35 & 3 & 13,04 & 1 & 4,35 \\
\hline Пассивность местного населения & 5 & 21,74 & 1 & 4,35 & 1 & 4,35 & 2 & 8,70 \\
\hline $\begin{array}{l}\text { Недостаточное внимание властей к пробле- } \\
\text { мам жителей }\end{array}$ & 3 & 13,04 & 1 & 4,35 & 1 & 4,35 & 1 & 4,35 \\
\hline Дефицит кадров местного самоуправления & 2 & 8,70 & 0 & 0 & 1 & 4,35 & 1 & 4,35 \\
\hline Ваш вариант (не знают, где этому учиться) & 1 & 4,35 & 1 & 4,35 & & & & \\
\hline
\end{tabular}

Примечание. Составлено авторами.

Таблицуа 2

Причины отказа граждан от принятия участия в местном самоуправлении

\begin{tabular}{|c|c|c|c|c|c|c|c|c|}
\hline \multirow{3}{*}{ Причины отказа от участия } & \multirow{2}{*}{\multicolumn{2}{|c|}{$\begin{array}{c}\text { Общее количество } \\
\text { респондентов }\end{array}$}} & \multicolumn{6}{|c|}{ Распределение в зависимости от стажа } \\
\hline & & & \multicolumn{2}{|c|}{ от 5 до 10 лет } & \multicolumn{2}{|c|}{ от 10 до 20 лет } & \multicolumn{2}{|c|}{ более 20 лет } \\
\hline & $\begin{array}{l}\text { Кол-во } \\
\text { чел. }\end{array}$ & $\%$ & $\begin{array}{l}\text { Кол-во } \\
\text { чел. }\end{array}$ & $\%$ & $\begin{array}{l}\text { Кол-во } \\
\text { чел. }\end{array}$ & $\%$ & $\begin{array}{l}\text { Кол-во } \\
\text { чел. }\end{array}$ & $\%$ \\
\hline $\begin{array}{l}\text { Привыкли надеяться на руководство го- } \\
\text { рода }\end{array}$ & 6 & 26,09 & 2 & 8,70 & 4 & 17,39 & 0 & 0 \\
\hline Безразличны к общим делам & 2 & 8,70 & 1 & 4,35 & 0 & 0 & 1 & 4,35 \\
\hline $\begin{array}{l}\text { Имеют недостаток знаний в вопросах са- } \\
\text { моуправления }\end{array}$ & 9 & 39,13 & 4 & 17,39 & 4 & 17,39 & 1 & 4,35 \\
\hline $\begin{array}{l}\text { Не верят в возможность оказывать влия- } \\
\text { ние на принимаемые решения админист- } \\
\text { рацией города }\end{array}$ & 5 & 21,74 & 2 & 8,70 & 1 & 4,35 & 2 & 8,70 \\
\hline $\begin{array}{l}\text { Убежденность, что каждый должен быть } \\
\text { сам за себя }\end{array}$ & 3 & 13,04 & 1 & 4,35 & 1 & 4,35 & 1 & 4,35 \\
\hline $\begin{array}{l}\text { Испытывают недостаток времени вслед- } \\
\text { ствие сверхнормативной загруженности } \\
\text { на работе }\end{array}$ & 13 & 56,52 & 4 & 17,39 & 4 & 17,39 & 5 & 21,74 \\
\hline Не доверяют органам местной власти & 3 & 13,04 & 1 & 4,35 & 1 & 4,35 & 1 & 4,35 \\
\hline
\end{tabular}

Примечание. Составлено авторами.

дан, по мнению 56,52 \% экспертов, является причина недостатка времени вследствие сверхнормативной загруженности на работе.

Ситуация, при которой люди, не доверяя органам управления, отказываются предоставлять им ресурсы, а без надлежащих ресурсов те не могут нормально исполнять свои функции, носит название «порочной спирали» государственного управления [3, с. 114]. Парадоксально, но уровень доверия органам местного самоуправления значительно ниже, чем региональным и федеральным органам власти, несмотря на то что местная власть более других приближена к населению. К тому же факт отсутствия доверия может провоцировать манипулирование общественным мнением уже на низовом уровне, имитацию гражданского участия, которое в действительности должно являться базовой основой местного политического процесса и местной демократии. 
Новые формы непосредственного участия населения в осуществлении местного самоуправления

Среди тех граждан, у которых активная позиция доминирует, имеются личные мотивы для участия в общественной жизни города. По мнению руководителей органов власти местного самоуправления, у таких граждан преобладают мотивы альтруистической направленности (табл. 3).

Удовлетворенность деятельностью органов местного самоуправления может быть выражена в различных оценках. Государство может задавать такие критерии, которые формально будут показывать положительную динамику, однако качественные изменения могут быть заметны лишь тогда, когда важным критерием оценки результативности данного института будет высокая степень активности участия граждан в разрешении вопросов местного значения. В рамках изучения мнения экспертного состава об отношении населения к местному самоуправлению нас интересовало, в какой сфере граждане наиболее активны в решении проблем местного значения (см. табл. 4). Проанализировав ответы экспертов по данному вопросу, можно увидеть, что, по их мнению, граждане наиболее активны в решении проблем местного самоуправления в сферах ЖКХ, социальной сфере, окружающей среды, общественного порядка, трудоустройства, культуры и отдыха.

Вполне понятно, что, если муниципальные органы власти заинтересованы в том, чтобы население принимало активное участие в решении вопросов местного значения, они стараются установить партнерские отношения с общественными и иными негосударственными некоммерческими организациями, которые постоянно вносят свой вклад в развитие муниципальных образований, тем са-

Основные мотивы участия населения в общественной жизни города

Таблица 3

\begin{tabular}{|c|c|c|c|c|c|c|c|c|}
\hline \multirow{3}{*}{ Основные мотивы } & \multirow{2}{*}{\multicolumn{2}{|c|}{$\begin{array}{l}\text { Общее количест- } \\
\text { во респондентов }\end{array}$}} & \multicolumn{6}{|c|}{ Распределение в зависимости от стажа } \\
\hline & & & \multicolumn{2}{|c|}{ от 5 до 10 лет } & \multicolumn{2}{|c|}{ от 10 до 20 лет } & \multicolumn{2}{|c|}{ более 20 лет } \\
\hline & $\begin{array}{l}\text { Кол-во } \\
\text { чел. }\end{array}$ & $\%$ & $\begin{array}{l}\text { Кол-во } \\
\text { чел. }\end{array}$ & $\%$ & $\begin{array}{c}\text { Кол-во } \\
\text { чел. }\end{array}$ & $\%$ & $\begin{array}{c}\text { Кол-во } \\
\text { чел. }\end{array}$ & $\%$ \\
\hline $\begin{array}{l}\text { Благоустройство окружающей среды в } \\
\text { городе }\end{array}$ & 20 & 86,96 & 4 & 17,39 & 8 & 34,78 & 8 & 34,78 \\
\hline $\begin{array}{l}\text { Потребность совершать социально полез- } \\
\text { ные и одобряемые обществом дела }\end{array}$ & 19 & 82,61 & 4 & 17,39 & 8 & 34,78 & 7 & 30,43 \\
\hline $\begin{array}{l}\text { Оказание помощи людям, попавшим в } \\
\text { трудную жизненную ситуацию (матери- } \\
\text { альная поддержка, содействие устройству } \\
\text { в социальные учреждения и т. д.) }\end{array}$ & 16 & 69,57 & 4 & 17,39 & 6 & 26,09 & 6 & 26,09 \\
\hline $\begin{array}{l}\text { Отстаивание прав социально незащищен- } \\
\text { ных граждан }\end{array}$ & 14 & 60,87 & 2 & 8,70 & 7 & 30,43 & 5 & 21,74 \\
\hline Личная активная гражданская позиция & 12 & 52,17 & 2 & 8,70 & 5 & 21,74 & 5 & 21,74 \\
\hline $\begin{array}{l}\text { Повышение общественного статуса чело- } \\
\text { века }\end{array}$ & 10 & 43,48 & 4 & 17,39 & 4 & 17,39 & 2 & 8,70 \\
\hline $\begin{array}{l}\text { Перспективы улучшения качества жизни } \\
\text { жителей города }\end{array}$ & 9 & 39,13 & 3 & 13,04 & 4 & 17,39 & 2 & 8,70 \\
\hline $\begin{array}{l}\text { Участие в разработке государственной } \\
\text { политики по усилению роли гражданско- } \\
\text { го общества }\end{array}$ & 9 & 39,13 & 3 & 13,04 & 4 & 17,39 & 2 & 8,70 \\
\hline $\begin{array}{l}\text { Возможность влияния на политику мест- } \\
\text { ной власти }\end{array}$ & 7 & 30,43 & 2 & 8,70 & 2 & 8,70 & 3 & 13,04 \\
\hline $\begin{array}{l}\text { Желание осуществлять идеи, проекты в } \\
\text { команде }\end{array}$ & 7 & 30,43 & 2 & 8,70 & 3 & 13,04 & 2 & 8,70 \\
\hline Отстаивание нарушенных прав граждан & 7 & 30,43 & 3 & 13,04 & 2 & 8,70 & 2 & 8,70 \\
\hline Перспектива дополнительного заработка & 5 & 21,74 & 3 & 13,04 & 1 & 4,35 & 1 & 4,35 \\
\hline $\begin{array}{l}\text { Возможность решения проблем личного } \\
\text { характера }\end{array}$ & 4 & 17,39 & 1 & 4,35 & 1 & 4,35 & 2 & 8,70 \\
\hline $\begin{array}{l}\text { Возможность выразить протест местной } \\
\text { власти муниципального образования }\end{array}$ & 2 & 8,70 & 1 & 4,35 & 0 & 0 & 1 & 4,35 \\
\hline $\begin{array}{l}\text { Желание осуществлять идеи, проекты ин- } \\
\text { дивидуально }\end{array}$ & 0 & 0 & 0 & 0 & 0 & 0 & 0 & 0 \\
\hline
\end{tabular}

Примечание. Составлено авторами. 
Наибольшая активность граждан в решении проблем местного самоуправления в определенных сферах

\begin{tabular}{|c|c|c|c|c|c|c|c|c|}
\hline \multirow{3}{*}{ Основные сферы } & \multirow{2}{*}{\multicolumn{2}{|c|}{$\begin{array}{c}\text { Общее количество } \\
\text { респондентов }\end{array}$}} & \multicolumn{6}{|c|}{ Распределение в зависимости от стажа } \\
\hline & & & \multicolumn{2}{|c|}{ от 5 до 10 лет } & \multicolumn{2}{|c|}{ от 10 до 20 лет } & \multicolumn{2}{|c|}{ более 20 лет } \\
\hline & $\begin{array}{c}\text { Кол-во } \\
\text { чел. }\end{array}$ & $\%$ & $\begin{array}{c}\text { Кол-во } \\
\text { чел. }\end{array}$ & $\%$ & $\begin{array}{c}\text { Кол-во } \\
\text { чел. }\end{array}$ & $\%$ & $\begin{array}{c}\text { Кол-во } \\
\text { чел. }\end{array}$ & $\%$ \\
\hline ЖКХ & 18 & 78,26 & 4 & 17,39 & 8 & 34,78 & 6 & 26,09 \\
\hline Социальная сфера & 13 & 56,52 & 4 & 17,39 & 5 & 21,24 & 4 & 17,39 \\
\hline Окружающая среда & 11 & 47,83 & 3 & 13,04 & 4 & 17,39 & 4 & 17,39 \\
\hline Общественный порядок & 10 & 43,48 & 3 & 13,04 & 3 & 13,04 & 4 & 17,39 \\
\hline Трудоустройство & 9 & 39,13 & 4 & 17,39 & 2 & 8,70 & 3 & 13,04 \\
\hline Культура и отдых & 8 & 34,78 & 2 & 8,70 & 3 & 13,04 & 3 & 13,04 \\
\hline Малый бизнес & 7 & 30,43 & 2 & 8,70 & 2 & 8,70 & 3 & 13,04 \\
\hline Обеспечение жильем & 6 & 26,09 & 2 & 8,70 & 1 & 4,35 & 3 & 13,04 \\
\hline Транспортная сфера & 5 & 21,74 & 2 & 8,70 & 2 & 8,70 & 1 & 4,35 \\
\hline Туризм & 5 & 21,74 & 1 & 4,35 & 3 & 13,04 & 0 & 0 \\
\hline Образование & 4 & 17,39 & 2 & 8,70 & 1 & 4,35 & 1 & 4,35 \\
\hline Медицина & 4 & 17,39 & 1 & 4,35 & 2 & 8,70 & 1 & 4,35 \\
\hline Миграционная политика & 3 & 13,04 & 0 & 0 & 3 & 13,04 & 0 & 0 \\
\hline
\end{tabular}

Примечание. Составлено авторами.

мым способствуют повышению качества жизни населения [8, p. 155].

Какие же меры, привлекающие граждан к участию в вопросах местного самоуправления, нужны, по мнению руководителей? По данным таблицы 5 видно, что самой эффективной мерой, привлекающей граждан к участию в вопросах самоуправления, является распространение информации в СМИ. Так считают 73,91\% экспертов.

Вопрос о мерах, привлекающих граждан к участию в вопросах самоуправления, в опросном листе предусматривал «Ваш вариант ответа». Эксперты не предложили свои варианты, так как одобрили предложенные, но от- метили, что многие варианты являются идеалистическими: администрация города не может предоставлять скидки по кредитам и ипотеке, так как на этот счет есть четкая законодательная позиция государства. То же и в отношении освобождения работника на дополнительный рабочий день с сохранением заработной платы: городская администрация не настолько испытывает дефицит кадров, чтобы идти на такие условия. Несмотря на столь критичные замечания, считаем, что меры, привлекающие граждан к участию в вопросах самоуправления, могут являться дополнительным аргументом в пользу гражданской активности, а также способствовать

Таблища 5

Меры, привлекающие граждан к участию в вопросах самоуправления

\begin{tabular}{|c|c|c|c|c|c|c|c|c|}
\hline \multirow{3}{*}{$\begin{array}{c}\text { Меры, привлекающие граждан к участию } \\
\text { в вопросах самоуправления }\end{array}$} & \multirow{2}{*}{\multicolumn{2}{|c|}{$\begin{array}{l}\text { Общее количест- } \\
\text { во респондентов }\end{array}$}} & \multicolumn{6}{|c|}{ Распределение в зависимости от стажа } \\
\hline & & & \multicolumn{2}{|c|}{ от 5 до 10 лет } & \multicolumn{2}{|c|}{ от 10 до 20 лет } & \multicolumn{2}{|c|}{ более 20 лет } \\
\hline & $\begin{array}{l}\text { Кол-во } \\
\text { чел. }\end{array}$ & $\%$ & $\begin{array}{l}\text { Кол-во } \\
\text { чел. }\end{array}$ & $\%$ & $\begin{array}{l}\text { Кол-во } \\
\text { чел. }\end{array}$ & $\%$ & $\begin{array}{c}\text { Кол-во } \\
\text { чел. }\end{array}$ & $\%$ \\
\hline $\begin{array}{l}\text { Распространять больше информации } \\
\text { через СМИ }\end{array}$ & 17 & 73,91 & 4 & 17,39 & 6 & 26,09 & 7 & 30,43 \\
\hline $\begin{array}{l}\text { Гарантировать освобождение у работ- } \\
\text { ника одного рабочего дня в неделю с } \\
\text { сохранением средней заработной платы }\end{array}$ & 4 & 17,39 & 1 & 4,35 & 2 & 8,70 & 1 & 4,35 \\
\hline $\begin{array}{l}\text { Организовать обучение граждан на } \\
\text { безвозмездной основе с отрывом от } \\
\text { производства }\end{array}$ & 3 & 13,04 & 2 & 8,70 & 1 & 4,35 & 0 & 0 \\
\hline $\begin{array}{l}\text { Предоставить доплату к основному } \\
\text { окладу }\end{array}$ & 1 & 2,35 & 1 & 4,35 & 0 & 0 & 0 & 0 \\
\hline $\begin{array}{l}\text { Предоставить скидку по ипотеке или } \\
\text { по кредиту за автомобиль }\end{array}$ & 1 & 4,35 & 1 & 4,35 & 0 & 0 & 0 & 0 \\
\hline
\end{tabular}

Примечание. Составлено авторами. 
разработке и реализации целевых программ, направленных на повышение общественной активности, в целях применения потенциала населения в помощь органам местного самоуправления в разрешении вопросов местного значения, что в условиях современности имеет особое значение.

В процессе исследования было выявлено, что наиболее единодушной в ответах на вопросы группой экспертов стали работники органов местного самоуправления с рабочим стажем от 5 до 10 лет. Пунктов опросного листа, где, не сговариваясь, эксперты отметили один и тот же вариант ответа, было 19; в группе респондентов со стажем 20 и более лет - 4 раза встречаются совпадения; в группе со стажем от 10 до 20 - 2 раза. Эксперты считают, что для населения понятие «местное самоуправление» в более чем половине случаев $(56,52 \%)$ является инициативой руководителя органа местного самоуправления, но большинство $(82,61 \%)$ экспертов отмечают, что участие населения в решении местных вопросов оказывает значительное влияние. При этом формами, которые больше всего устраивают местное население, выступают ТОС, ТСЖ, обращения граждан в органы местного самоуправления, сходы граждан и муниципальные выборы. Наиболее активное участие граждан в решении проблем местного самоуправления эксперты отмечают в сфере ЖКХ, социальной сфере, сфере окружающей среды и общественного порядка. Основными мотивами участия граждан в жизни города выступают благоустройство окружающей среды в городе; потребность совершать социально полезные и одобряемые обществом дела; оказание помощи людям, попавшим в трудную жизненную ситуацию (материальная поддержка, содействие устройству в социальные учреждения и т. д.); отстаивание прав социально незащищенных граждан; личная активная гражданская позиция. Эксперты отмечают в большинстве случаев среднюю активность избирателей, а в более чем $20 \%$ случаев высокую. По мнению экспертов, основу социальной базы местного самоуправления могут составить такие социальные группы, как члены общественных организаций, руководители предприятий и организаций и пред- ставители интеллигенции (учителя, преподаватели, научные работники).

Однако существуют причины, которые, по мнению экспертов, препятствуют проявлению инициатив граждан. Наиболее значимыми являются отсутствие баланса интересов муниципальной власти, государственной власти, населения, бизнеса; несовершенное законодательство; занятость делами личного характера; бюрократия при взаимодействии с органами государственной власти и неорганизованность жителей. Нежелание участвовать в местном самоуправлении проявляется в основном из-за недостатка времени вследствие сверхнормативной загруженности на работе; недостатка знаний в вопросах самоуправления.

Описанные нами проблемы не представляют уникальности, они наблюдаются и в других странах. Интересным является путь решения рассмотренных проблем, предложенный участниками некоммерческого форума «Тhe Crossing Boundaries National Council» и сотрудниками канадского исследовательского центpa «Canada 2020», которые разработали форму общественного диалога с целью нормализации активного участия населения в местном самоуправлении [9, р. 17]. Данная форма диалога имеет в основе ряд положений:

1. Представление о том, что муниципалитеты планируют и проводят политику, а также несут полную ответственность за развитие муниципальных образований, устарело и нуждается в изменении.

2. Роль муниципалитетов в управлении муниципальными образованиями как организатора этого процесса, а также партнера всех заинтересованных в развитии муниципального образования групп населения.

3. Для результативного управления муниципальным образованием необходим диалог. Разные общественные группы должны быть включены в диалог с разными целями и с использованием разных видов диалога.

4. Общественное участие в управлении муниципальными образованиями предполагает активную деятельность неформальных лидеров, которые желают и имеют возможность брать на себя ответственность за решение проблем, стоящих перед муниципальными образованиями. 
Таким образом, повышение эффективности участия граждан в организации местного самоуправления возможно путем ориентации местного самоуправления на удовлетворение потребностей граждан. Для проведения реформ институтов местного самоуправления требуется обязательное согласование по трем основным принципам:

1. Система управления ориентируется на нужды населения. Данный принцип направлен на оказание услуг в соответствии с определенным приоритетом гражданского сообщества.

2. Ответственное управление. Органы местного управления обязаны правильно распределять свои финансовые ресурсы. Местными органами власти заслуживается доверие жителей высоким качеством работы при минимальных затратах на содержание и эффективным управлением финансовыми и социальными рисками сообщества. Органами местного управления также повышается качество, количество и доступность муниципальных услуг для населения. Для достижения цели требуется использовать в работе эффективные модели организации местного самоуправления.

3. Отчетность управления. Органами местного самоуправления составляется отчет о проделанной работе перед своими избирателями для гарантии соблюдения интересов сообщества, а также предоставление отчета перед гражданами в период между выборами, а следовательно, выявляется необходимость реформирования в области законодательства и институтов власти. Например, введение хартии о правах граждан и положения об отзыве должностного лица из органов управления [5, с. 73$]$.

Модель местного самоуправления, основанная на данных принципах, обладает следующими характерными признаками: гражданское сообщество законодательно наделено полномочиями (положение о прямой демократии, хартия о правах граждан); органы власти отчитываются перед гражданами за результаты своей работы; производится оценка работы органов власти как посредников в сфере предоставления муниципальных услуг, поскольку именно граждане управляют, платят налоги и пользуются данными услугами.
Таким образом, следует отметить, что проведенные исследования показали неготовность населения принимать деятельное и постоянное участие в осуществлении местного самоуправления, что обусловлено целым комплексом причин, носящих, прежде всего, субъективный характер, следовательно, целесообразно вовлечение жителей в решение местных проблем через развитие добровольных объединений граждан, деятельность которых будет направлена на социально значимые задачи.

\section{ПРИМЕЧАНИЕ}

1 Работа выполнена в рамках гранта РФФИ № 16-12-34012 «Формирование и совершенствование механизма коммерциализации научно-технических разработок в регионах РФ» при поддержке Администрации Волгоградской области.

\section{СПИСОК ЛИТЕРАТУРЫ}

1. Буянова, М. Э. Совершенствование процесса интеграции менеджмента качества и системы государственного и муниципального управления / М. Э. Буянова, Н. А. Михайлова // Известия вузов. Инвестиции. Строительство. Недвижимость. - 2015. - № 4. - С. 9-17.

2. Инновационные технологии развития бизнеса и предпринимательских структур : материалы междунар. науч.-практ. конф. / отв. за вып. Я. В. Мещерякова. - Вроцлав : Фонд «Русско-польский институт», 2016. $-212 \mathrm{c}$.

3. Малган, Дж. Искусство государственной стратегии. Мобилизация власти и знания во имя всеобщего блага / Дж. Малган. - М. : Ин-т Гайдара, 2011. - С. 114-115.

4. Михайлова, Н. А. Инновационные формы и механизмы формирования концепции эффективного муниципального управления / Н. А. Михайлова // Вестник Волгоградского государственного университета. Серия 3, Экономика. Экология. 2016. - № 3 (36). - C. 127-134. - DOI: https://doi.org/ 10.15688/jvolsu3.2016.3.12.

5. Повышение эффективности местного самоуправления: стратегический аспект : монография / под общ. ред. В. В. Курченкова. - Волгоград : Изво ВолГУ, 2016. - 120 с.

6. Трофимова, И. Н. Эффективность местного самоуправления в Российской Федерации и проблема гражданского участия / И. Н. Трофимова // ARS ADMINISTRANDI. - 2012. - № 3. - C. 62-63. 
7. Формы участия населения в осуществлении местного самоуправления: опыт сибирских регионов / под ред. Н. Н. Ждановой, В. Н. Лисицы. - Новосибирск, 2015. - 158 с.

8. Babich, T. V. Improvement of the regional agroindustrial complex state support mechanism in conditions of international sanctions and Russia's membership in the WTO/T. V. Babich, N. A. Mikhaylova // Overcoming uncertainty of institutional environment as a tool of global crisis management. - N. Y. : Springer, 2017. - P. 151-157.

9. Progressive Governance for Canadians: What You Need To Know / D. Lenihan, T. Barber, G. Fox, J. Milloy. - Ottawa, 2017.

\section{REFERENCES}

1. Buyanova M.E., Mikhaylova N.A. Sovershenstvovanie protsessa integratsii menedzhmenta kachestva i sistemy gosudarstvennogo i munitsipalnogo upravleniya [Improving the Process of Integration of Quality Management and the System of State and Municipal Management]. Izvestiya vuzov. Investitsii. Stroitelstvo. Nedvizhimost, 2015, no. 4, pp. 9-17.

2. Meshcheryakova Ya.V., ed. Innovatsionnye tekhnologii razvitiya biznesa i predprinimatelskikh struktur: materialy mezhdunarodnoy nauchnoprakticheskoy konferentsii [Innovative Technologies for Business Development and Entrepreneurial Structures: Proceedings of the International Scientific and Practical Conference]. Wroclaw, Russian-Polish Institute, 2016. $212 \mathrm{p}$.

3. Malgan J. Iskusstvo gosudarstvennoy strategii. Mobilizatsiya vlasti $i$ znaniya vo imya vseobshchego blaga. [The Art of Public Strategy.
Mobilizing Power and Knowledge for the Greater Good]. Moscow, In-t Gaydara, 2011, pp. 114-115.

4. Mikhaylova N.A. Innovatsionnye formy i mekhanizmy formirovaniya kontseptsii effektivnogo munitsipalnogo upravleniya [Innovative Forms and Mechanisms for Creating the Conception of Effective Municipal Management]. Vestnik Volgogradskogo gosudarstvennogo universiteta. Seriya 3: Ekonomika. Ekologiya [Science Journal of Volgograd State University. Global Economic System], 2016, no. 3 (36), pp. 127-134. DOI: https://doi.org/10.15688/jvolsu3.2016.3.12.

5. Povyshenie effektivnosti mestnogo samoupravleniya: strategicheskiy aspekt: monografiya [Improving the Effectiveness of Local Self-Government: Strategic Aspect. Monograph]. Volgograd, Izd-vo VolGU, 2016. 120 p.

6. Trofimova I.N. Effektivnost mestnogo samoupravleniya v Rossiyskoy Federatsii i problema grazhdanskogo uchastiya [The Effectiveness of Local Self-Government in the Russian Federation and the Problem of Civic Engagement]. ARS ADMINISTRANDI, 2012, no. 3, pp. 62-63.

7. Zhdanova N.N., Lisitsa V.N. Formy uchastiya naseleniya vosushchestvlenii mestnogo samoupravleniya: opyt sibirskikh regionov [Forms of Public Participation in the Local Self-Government: the Experience of the Siberian Regions]. Novosibirsk, 2015. 158 p.

8. Babich T.V., Mikhaylova N.A. Improvement of the regional agro-industrial complex state support mechanism in conditions of international sanctions and Russia's membership in the WTO. Overcoming uncertainty of institutional environment as a tool of global crisis management. New York, Springer, 2017, pp. 151-157.

9. Lenihan D., Barber T., Fox G., Milloy J. Progressive Governance for Canadians: What You Need To Know. Ottawa, 2017.

\section{Information about the Authors}

Valeriya A. Rodkina, Chief Specialist, Regional Center for Development and Quality Control of Social Services, Novorossiyskaya St., 41, 400087 Volgograd, Russian Federation, valery_rodkina@mail.ru.

Nataliya A. Mikhaylova, Candidate of Sciences (Economics), Associate Professor, Department of State and Municipal Management, Volgograd State University, Prosp. Universitetsky, 100, 400062 Volgograd, Russian Federation, korish.m@volsu.ru.

\section{Информация об авторах}

Валерия Александровна Родькина, главный специалист, Областной центр развития и контроля качества социальных услуг, ул. Новороссийская, 41, 400087 г. Волгоград, Российская Федерация, valery_rodkina@mail.ru.

Наталия Александровна Михайлова, кандидат экономических наук, доцент кафедры государственного и муниципального управления, Волгоградский государственный университет, просп. Университетский, 100, 400062 г. Волгоград, Российская Федерация, korish.m@volsu.ru. 